\title{
FAKE AS A METHOD OF MANIPULATION IN THE MEDIA: UKRAINIAN EXPERIENCE
}

The article describes the characteristics of "fake", "fake news". The manipulative technologies in the media are considered. According to the author, today the users of social networks constantly see false information, written and disseminated in order to increase internet traffic. Extremely dangerous is the "news" created to discriminate on the basis of gender, race, nationality, language, origin, religion, affiliation with any social group, political beliefs, and also information distributed in order to fraudulently seize cash (for example, a message about raising funds for the treatment of seriously ill children).

Attention is drawn to the fact that fakes are used as a powerful means of manipulating public consciousness. This is because today the direct ideological pressure on the recipient is applied much less than before, and other means, mainly manipulative, are used for "unobtrusive" imposition.

It is annoying that consumers of information can not always distinguish fake from reality, propaganda message from true. Among the news headlines, there is also media content placed on the pages of fake publications, which by their titles impress, shock the user. They attract increased attention and interest from people who continue to spread the false news by wanting to reach a larger audience, share it with their social networking friends, thus becoming a propaganda tool.

On the eve of the 2019 elections some Ukrainian media published the results of questionable polls or incorrectly submitted data from reputable sociological organizations, which became an instrument of campaigning for specific presidential candidates.

Emphasized on that fact, that related to presidential candidates media disseminated polls to specific politicians.

According to the author, referring to the results of various studies, on the TV channel "1 + 1" more often talked about high ratings of Volodymyr Zelenskyi, in the news "Inter" about the leadership of Yuriy Boyko, and on the TRK "Ukraina" - about the possible victory of Olexander Vilkul.

Key words: fake; fake news; manipulation technologies; media discourse; propaganda techniques; consciousness manipulation.

Ірина Пуцята

\section{ФЕЙК ЯК МЕТОД МАНІПУЛЯЦІї У ЗМІ: УКРАЇНСЬКИЙ ДОСВІД}

Подано характеристику понять “фейк”, “фейкові новини”. Розглянуто маніпулятивні технології в ЗМІ. На думку автора, сьогодні користувачі соціальних мереж постійно бачать неправдиву інформацію, написану i поширену 3 метою підвищення 
інтернет-трафіку. Надзвичайно небезпечні ті “новини”, які створюють 3 метою дискримінації за ознаками статі, раси, національності, мови, походження, ставлення до релігії, належності до якої-небудь соціальної групи, політичних переконань, а також інформація, поширена для того, щоб шахрайським способом заволодіти грошовими коштами (наприклад, повідомлення про збирання коштів на лікування тяжкохворих дітей).

Звернено увагу на те, що фейки використовуються як потужний засіб маніпулювання суспільною свідомістю. Це відбувається тому, що сьогодні прямий ідеологічний тиск на реципіснта застосовусться значно рідше, ніж раніше, і 3 метою “ненав'язливого нав'язування" використовуються інші засоби, здебільшого маніпулятивні.

Прикро, що споживачі інформації не завжди можуть відрізнити фейк від дійсності, пропагандистське повідомлення від правдивого. Серед заголовків новин трапляється і медіаконтент, розміщений на сторінках фейкових видань, які своїми назвами вражають, шокують користувача. Вони викликають підвищену увагу й інтерес у людей, які й поширюють далі неправдиві новини, поділитися ними зі своїми друзями із соціальних мереж, бажаючи залучити більшу аудиторію, тим самим перетворюючись на інструмент пропаганди.

Напередодні виборів 2019 р. деякі українські медіа публікували результати сумнівних опитувань або некоректно подавали дані авторитетних соціологічних організацій, що стало інструментом агітації за конкретних кандидатів у президенти.

Акцентовано на тому, що пов'язані з кандидатами в президенти ЗМІ поширювали статистичні дані опитувань на користь конкретних політиків.

На думку автора, посилаючись на результати різних досліджень, в ефірі телеканалу “1+1" частіше говорили про високі рейтинги Володимира Зеленського, в новинах "Інтер" - про лідерство Юрія Бойка, а на ТРК “Україна" - про можливу перемогу Олександра Вілкула.

Ключові слова: фейк; фейкові новини; технології маніпуляції; медійний дискурс; пропагандистські прийоми; маніпулювання свідомістю.

Formulation of the problem. Today, various techniques and manipulation strategies are actively used on the pages of print media, on television channels and on the Internet site. In this case, it does not matter what type of media gravitates to: quality or mass media. Therefore, it is very important for media to find false information and neutralize it before it is distributed to the general public. Misleading, generating rumors, inflating social tension are all fakes that have deeply embedded their "contaminated roots" into all-Ukrainian media. Most often false information is available on various sites on the Internet, social networks. The reason for this is the lack of control of moderators of social communities, and consumers themselves do not analyze or reflect on the read and seen material. The internet is already so full of fakes that it is becoming more and more difficult to figure out where the fictional and the true are among the vast array of materials. The media, in spite of their duty to reflect public opinion, create it. It should be noted that, unfortunately, the manipulation of social consciousness in our time has become a global socio-political reality.

Analysis of recent research and publications. The essence of manipulative influence on the subconscious of people is the subject of constant attention of both domestic and foreign researchers (G. Pocheptsov [9], G. Ortega-i-Gasset [7], D. Olshanskyi [6], S. Kara-Murza [3], M. Libiki [4], G. Schiller [21], C Siomin [16], P. Lainbardjer [5], M. Senchenko [12], O. Ryabokon [11], O. Pryhornytska [10]), however, the writings of scientists do not pay attention to the "fake virus", which has become ill Ukrainian media.

Purpose - to investigate the nature of fake as a method of manipulation in the Ukrainian media. 
Presenting main material. The word "fake" (from the English "fake" - false, plugged; the colloquial variant - phony), with its negative pragmatics, has become widely used in the last decade. It is included in the "Dictionary of Fashion Words", and it states that this definition is not just fashionable, but "super-fashionable, mega-fashionable" [2]. Equally often used is the adjective "fake". Recently, it has become extremely relevant to spread false news, fabricated materials that mislead recipients. The phenomenon itself is not new (the concept of "newspaper duck" for at least three hundred years), but the increase in information channels not only did not provide the transparency and accuracy of data, as it was expected, but also became a factor in the multiple increase in lies. If in the traditional media of the Soviet period news was carefully checked for authenticity and doubtful were not published (because, always, there were "corrections" caused by ideology), today the fake - an exception that testifies to the unprofessionalism or dishonesty of its creator, the lie became this creator, the method of formation of information space. That is why there is so much research attention on the phenomenon of fakes and fake news in modern science. Nowadays, media practitioners often say that the authorities and the society need not as much truth, as information that is similar to the truth, but not the truth in fact. Such tendencies in the development of the media lead to the fact that "fact journalism" is occupied by "credible journalism", as well as "opinion journalism" and even "impression journalism". This is evidenced by the widespread distribution of fakes [13]. When the purpose of publishing and distributing news is merely to attract the attention of readers, a great deal of false information appears [15, p. 15]. False material can distract the audience from a really meaningful and important message; Fake news on the Internet serves to increase popularity (and effective in this case is a "black" PR) or earnings: sensational details about famous people pass each other, comment, make reposts, which increases the popularity of the resource and generates profit. Manipulative influence is characterized by the following stable indicators: it is carried out purposefully and secretly; contains algorithms for programming both thinking and perception and behavior of an object; includes methods and techniques by which it imparts targeted pressure on the psyche, the second signaling system and the components of consciousness of the object of influence [8]. Information flows collapse into the mass consciousness, deprive the mass media consumer of the opportunity to actively (critically) process them, leaving him only a passive role, which is a prerequisite for propaganda influence.

S. N. Ilchenko writes about fake journalism as an element of show civilization [2]. According to the author, show-civilization is a modern system of information relations in the society with contradictory, complex relations between reality, constructed by television and empirical reality as a result of creating news content. In fact, the question of reliability of information is virtually ignored, since the principles of efficiency and clarity are more important than truth and objectivity. Fake is a phenomenon of information environment that is closely linked to another (even more global) phenomenon - show civilization, that simulates reality through the construction of virtual reality in electronic media and the Internet. Speed and visual clarity of a particular "picture" in terms of news impressions is more important to the audience than ordinary verbal (text) information. In this case, in the combination of "picture + text" and "picture + sound", the image itself weighs. Manipulative information is formed not only at the expense of "opposition to epistemological truth" [9], but also at the expense of speed of introduction of the text message. Journalist not only presents the news, but in one way or another, comments and explains it. Depending on its goals, it can bring to the public a wide variety, including provocative points of view, to push and comment on them, giving the public an idea of wealth, diversity of views and opinions, or, conversely, not to give the audience access to untrue, trendy information. The material is based on unverified testimonies of individuals who were allegedly witnesses of any events, forms a pure fake. False news may be created solely for the purpose of consumer entertainment.

In the Internet age, anyone with access to the Internet can produce, distribute and receive information. Initiative bloggers begin to act as journalists, which, on the one hand, complies with basic democratic principles, and on the other hand, the self-proclaimed assignment of the media leads to the 
neglect of the principles of dealing with facts [13]. The fakes that are created, of course, are beyond social norms and professional journalistic ethics. It is clear that in the work of the media not only seek to fulfill its high social mission, but also to bring profit to the editorial staff and the owner of the information resource. This fact generates a desire for sensationalism at all costs, leading to the simplification of news in the pursuit of a mass audience. Each fake information has the purpose of misinforming, which means manipulating the audience. In our study, we identified several types of such a negative phenomenon:

1. Increase in digital metrics: $90 \%$ in Ukraine are outside poverty (no media outlets have provided such information, the author does not cite sources or statistics) [22].

2. Generalizing digital metrics: Medical reform gave its results. Over the last year, the number of patients in medical institutions has decreased threefold, and thus the population of Ukraine became healthier twice (the journalist expresses his opinion without any documentary evidence) [17].

3. Hyperbolization of phenomena and consequences: We have 5 times higher prices than in Poland, and salaries are $\mathbf{1 0}$ times lower than in Belarus (information is provided without statistics, the viewer is not able to verify the facts presented) [17].

4. Identification of events and phenomena with persons: Poroshenko ordered to forbid Russian observers access to Ukrainian elections (at the time of writing, P. Poroshenko had not yet signed this bill) [18].

On the eve of the 2019 elections, some Ukrainian media published the results of questionable polls or incorrectly provided data from reputable sociological organizations. Thus, materials about the electoral preferences of Ukrainians become an instrument of campaigning for specific presidential candidates.

"The professional community of sociologists is worried about how more fake and unprofessional sociological data are emerging in the media content", the Sociological Association of Ukraine said. - The media publish these materials citing unknown or little-known centers without mandatory methodological information for assessing the quality of the data" [13].

Many untrue material is covered by the $1+1$ channel. On March 23, 2019, one of the programs on this TV channel, incumbent President of Ukraine Petro Poroshenko was accused of killing his own brother. The dirtiest compromises are thrown out before the election. From a moral point of view, the channel should officially disprove this information. And indeed, the position of journalists and media owners is very important here [17].

Affiliates with the presidential candidates media broadcast the results of polls in favor of specific politicians. This was discussed in the media detector, which regularly analyzes the publications of the main Ukrainian media [1].

The so-called "spiral of silence" is a theory of mass communication that claims that people conceal their point of view if most do not share it and, on the contrary, happily identify with popular views. In sports, there is a similar phenomenon to "glory" - fans who cheer for the team only when it is on top. This is what journalists are striving for: to make people afraid to lose their voice by casting him as an outsider, and instead want to support the champion. Publication of the results of questionable polls or incorrect submission of data by the most reputable sociological organizations may partially influence the election results. There are always voters who are undecided and likely to vote in favor of the majority. They may be affected by the manipulation of sociological data.

However, it is difficult to trace the results of such an impact. "There is a threat that the supporters of the leader will not vote because so many people will vote for him", Mikhail Mishchenko said during a roundtable on Sociology and Elections: An Argument for Prudent Choice or Manipulation?, organized by the Democratic Initiatives Foundation. Ilka Kucheriv and the Sociological Association of Ukraine.

Iryna Bekeshkina also believed that the results of manipulations with sociological data should not be overestimated. "The biggest impact will be felt during the parliamentary elections, when people will pay attention to the rankings to cast their votes for "pass-through "parties" [14]. 
According to the sociologist, the publication of the results of questionable surveys or incorrect submission of data from the most reputable sociological organizations can affect the level of public trust in sociologists. "Unfortunately, journalists often put a mark in the same way between presidential candidates and sociology ratings. However, population surveys occupy a small place in sociological science" [14].

According to a recent survey by the Kiev International Institute of Sociology, Ukrainians' confidence in election polls is $43 \%$. At the same time, $20 \%$ of those polled said they did not trust the results of sociological research.

Conclusions. New information technologies have significantly changed the models of modern media, the speed of news transmission, and allowed readers to fulfill some of the duties of journalists, which turned them into content producers. Thousands of social network users write from the scene, and bloggers express their opinions about major social events.

The whole society is suffering from the use of fakes. They can provoke "terrorist attacks" of enormous destructive power. Therefore, negative trends associated with the use of false information must be described, studied and analyzed in order to avoid manipulative effects on people's subconscious.

The article has actual scientific and practical importance, gaining in the framework of the formation of the information society of particular importance for the decoding of propaganda technologies used by journalists in their work. Thus, fake as a method of manipulation in the media can be the basis for further research, because in-depth analysis is quite modest, in the domestic and foreign literature there is a lack of specialized works on the problem, which led to the choice of the topic of the article for research.

\section{References}

1. Media detector [Electronic resource]. Access mode: https://detector.media.

2. Ilchenko S. N. Fake in the practice of electronic media: criteria of authenticity // Mediaskop. 2016. Issue. 4. [Electronic resource]. URL: http://www.mediascope.ru/2237.

3. Kara-Murza S. Manipulation of consciousness / Sergei Kara-Murza. Moscow: Media Book, 2005. $500 \mathrm{p}$

4. Libiki M. "What is the information war?" [Electronic resource] / M. Libiki. Access mode: http://viysko.com.ua/texnologiji-voyen/martin-libiki-shho-take-information-screw.

5. Lainbardjer P. Psychological war. Theory and Practice of Mass Consciousness Processing / P. Linebarger. M.: Tsentrpoligraf, 2013. 445 p.

6. Olshanskyi D. V. Mass sentiment in politics / Olshanskyi D. V. M., 1995. 272 p.

7. Ortega-i-Gasset $H$. The revolt of the masses // Ortega-i-Gasset $H$. The revolt of the masses. Dehumanization of art. Invertebrate Spain. M.: AST: ST Moscow, 2008. 347 p.

8. Potyatynyk B. Internet journalism / B. Potyatynyk. Lviv: PAIS, 2010. P. 66.

9. Pocheptsov G. Modern information wars / G. Pocheptsov. K.: Kind. House: Kyiv-Mohyla Academy, 2015. 468 p.

10. Pryhornytska O. Regional mass media as a tool for manipulation of public opinion [Electronic resource] / O. Pryhornytska // NAS of Ukraine, Nat. b-ka of Ukraine them. V. I. Vernadsky, Assoc. b-to Ukraine. Kyiv, 2015. Issue. 41. P. 588-600. Access mode: http://nbuv.gov.ual UJRN/npnbuimviv_2015_41_45.

11. Ryabokon' $O$. Manipulations of mass consciousness in the political segment of social networks [Electronic resource] / O. Ryabokon' // NAS of Ukraine, Nat. b-ka of Ukraine them. V. I. Vernadsky, Assoc. b-to Ukraine. Kyiv, 2012. Issue. 33. P. 543-553. Access mode: http://nbuv.gov.ual UJRN/npnbuimviv_2012_33_50.

12. Senchenko M. Fourth World. Information-psychological war / M. Senchenko. Kyiv: MAUP, 2006. $64 \mathrm{p}$. 
13. Social Media [Electronic resource] // Wikipedia: The free encyclopedia. Access mode: https://en.wikipedia.org/wiki/.

14. Sociology and Election: An Argument for Mental Choice or Manipulation [Online resource]. Resource Access Mode: https://www.youtube.com/watch?v=yVt5YIP_PgI

15. Sulyma Mykola. New Russia as a fake, or Something about a historical fallacy for those who do not want to know the truth [Text] / M. Sulyma // Day. 2016. - No. 4/5 (15-16).

16. Siomin S. V. Separatism as a Threat to National Security of Ukraine / S. V. Siomin. // Strategic Priorities. Kiev: NISD, 2006. No. 3. S. 143-149.

17. TSN [Electronic resource]. - Access mode: https://tsn.ua.

18. Ukrains'ka Pravda [Electronic resource]. - Access mode: https://www.pravda.com.ua.

19. Fake News [Electronic resource] // Wikipedia: The free encyclopedia. Access mode: https://en.wikipedia.org/wiki/.

20. Tsukanova O. V. Information Wars: Impact on Society. [Electronic resource] / O. V. Tsukanova. Access mode: http://www.sworld.com.ua/konfer34/800.pdf.

21. Schyller G. Manipulators of consciousness / G. Schyller; trans. with English.; scientific ed. Ya. N. Zasursky. Moscow: Thought, 1980. 326 p.

22. UA. Review [Electronic resource]. Access mode: http://uareview.com. 